\title{
Transformation of Lower Alkanes into Aromatic Hydrocarbons over ZSM-5 Zeolites
}

\author{
Yoshio Ono*, Hiroyoshi Kitagawa, and Yoko Sendoda \\ Department of Chemical Engineering, Tokyo Institute of Technology \\ Ookayama, Meguro-ku, Tokyo 152
}

(Received July 5, 1986)

\begin{abstract}
The yields of aromatic hydrocarbons in the transformation of lower alkanes over ZSM-5 zeolites are greatly enhanced by incorporation of gallium or zinc cations into the zeolites. Effects of contact time on the product distribution in the conversion of hexane over H-ZSM-5 and Ga-ZSM-5 were examined in detail in order to obtain information on the reaction pathway. When contact time is short, only cracking of hexane prevails and when the time is extended, the olefins formed by cracking are converted into aromatics. It is concluded that gallium cations do not affect the capacity for hexane cracking, but they enhance the activity and efficacy for aromatization of olefins. Aromatization of propylene proceeds much more effectively over Zn-ZSM-5 than over H-ZSM-5. The lower yield of propane over Zn-ZSM5 indicates that zinc cations serve as a catalyst for dehydrogenation of olefinic species. While $\mathrm{Zn}$-borosilicate is not effective for promoting propane activation, it is effective for promoting propylene aromatization. It gives high benzene selectivity at low conversion level, indicating the intermediacy of allylic species in the aromatization reaction.
\end{abstract}

\section{Introduction}

Transformation of lower alkanes into more useful compounds like aromatics is of great importance since such transformation expands the sources of chemical products. Csicsery has described hydrocyclodimerization of lower alkanes over bifunctional

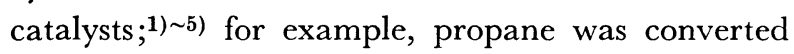
into aromatic hydrocarbons with $21 \%$ selectivity over platinum supported on alumina. ${ }^{2}$ Recently, ZSM-5 zeolites in combination with transition metals have been reported as the catalysts for aromatization of ethane ${ }^{6) \sim 8)}$ and propane. ${ }^{9)}$ Furthermore, ZSM-5 zeolites modified with gallium or zinc cations have been claimed to give high selectivities for aromatics. ${ }^{10), 11)}$ However, the mechanism of activation of lower alkanes and the role of metal cations in aromatization have not been well-established. Mole et al. ${ }^{12}$ ) have studied the conversion of propane over ZSM-5 exchanged with zinc cations (Zn-ZSM-5) and concluded that zinc cations abstract hydride ions from propane molecules. Ono et al. have studied the conversion of propane ${ }^{13}$ ) and pentane ${ }^{14)}$ over ZSM-5 zeolites and concluded that acidic sites are responsible for activation of alkanes, which undergo cracking, and that gallium cations enhance the rate of aromatization of inter-

* To whom correspondence should be addressed. mediate olefins. This work concerns with the transformation of lower alkanes into aromatic hydrocarbons over ZSM-5. The mechanistic pathway of hexane to aromatics over H-ZSM-5 and Ga-ZSM5 was studied, and the role of gallium ion-exchange was discussed. The reaction of propylene over $\mathrm{Ga}-$ ZSM-5 and Zn-ZSM-5 was also studied to acquire the knowledge of interaction between olefin molecules and metal cations. To observe the role of acidic sites in aromatization, reactions of olefins over borosilicates, which are known to have very weak acidities ${ }^{15) ~ 17)}$, were also carried out.

\section{Experimental}

ZSM-5 zeolites of varying $\mathrm{SiO}_{2} / \mathrm{Al}_{2} \mathrm{O}_{3}$ ratios were synthesized by the method described in a patent literature. ${ }^{18)}$ The structure of the synthesized materials was confirmed by X-ray diffractions to be that of ZSM-5 zeolite. The synthesized materials were converted into the ammonium forms $\left(\mathrm{NH}_{4}^{-}\right.$ ZSM-5)using the procedures described by Jacobs. ${ }^{19)}$ $\mathrm{Ga}^{3+}$ cations were introduced into $\mathrm{NH}_{4}-\mathrm{ZSM}-5$ using the ion-exchange procedure; i.e., $\mathrm{NH}_{4}-\mathrm{ZSM}-5$ was stirred in aqueous solution of $\mathrm{Ga}\left(\mathrm{NO}_{3}\right)_{3} 9 \mathrm{H}_{2} \mathrm{O}$ under refluxing conditions for $24 \mathrm{~h}$, filtrated, washed with water, and dried. Zn-ZSM-5 was prepared by exchanging three times in zinc nitrate solution at $80^{\circ} \mathrm{C}$ for $24 \mathrm{~h}$. Borosilicates with the ZSM-5 
structure were prepared according to the method described in a patent literature. ${ }^{20}$ The borosilicates also were changed to their ammonium, gallium, and zinc forms. The catalysts were pressed, crushed, and sorted into sizes of 16-32 mesh.

Reactions were carried out with a continuous flow reactor operating at atmospheric pressure. The catalyst was packed in a reactor (a $10 \mathrm{~mm}$-i.d. silica-tubing) placed in a vertical furnace, and was then heated in a stream of air at $580^{\circ} \mathrm{C}$ for $90 \mathrm{~min}$. By this treatment, it was assumed that $\mathrm{NH}_{4}-\mathrm{ZSM}-$ 5 form would be converted into the proton form (H-ZSM-5). Hexane and other liquid reactants were fed into the preheating zone of the reactor with a motor-driven syringe. Gaseous reactants were fed into the reactor through a flowmeter. The effluent gas was withdrawn periodically and analyzed with gas chromatography equipped with a flame ionization detector. Aliphatic and aromatic hydrocarbons were determined in a $2 \mathrm{~m}$-long Porapak Q column and a $30 \mathrm{~m}$-long OV-101 capillary-column, respectively.

Conversion, yield and selectivity, and product distribution were expressed on a carbon number basis, unless expressed otherwise.

\section{Results and Discussion}

\subsection{Conversion of Lower Alkanes}

The reactions of propane, pentane, and hexane over H-ZSM-5 and over Ga-ZSM-5 were carried out, and their total conversions and product distributions are summarized in Table 1. For propane, the reaction was carried out also over Zn-ZSM-5. Studies on the reactions of propane ${ }^{13)}$ and pentane ${ }^{14)}$ have been described in greater detail elsewhere.

Concerning the reaction of propane, the yield of aromatics appreciably increased by introducing zinc or gallium cations into ZSM-5. The selectivity to aromatics also increased; it was $30.0 \%, 49.9 \%$, and $72.2 \%$ over H-ZSM-5, Zn-ZSM-5, and Ga-ZSM5 , respectively. Instead, the selectivity to undesirable products, methane and ethane, decreased by introducing these cations. Aromatic hydrocarbons produced were mainly benzene, toluene, and xylenes. The benzene fraction in the aromatics was greater over $\mathrm{Zn}-$ and $\mathrm{Ga}-\mathrm{ZSM}-5$ than over $\mathrm{H}-$ ZSM-5. These results will be discussed in subsequent sections.

Ga-ZSM-5 was much more effective than $\mathrm{H}$ ZSM-5 also in the aromatization of pentane and hexane. In order to obtain information on the role of metal cations in the aromatization, the conversion of hexane was studied in detail.

\subsection{Conversion of Hexane}

Effect of reaction temperature. Conversion of hexane was carried out over H-ZSM-5 and over $\mathrm{Ga}-\mathrm{ZSM}-5 \quad\left(\mathrm{SiO}_{2} / \mathrm{Al}_{2} \mathrm{O}_{3}=42\right)$ under $101 \mathrm{kPa}$ of hexane at $\mathrm{W} / \mathrm{F}$ of $35.2 \mathrm{~g} \cdot \mathrm{h} \cdot \mathrm{mol}^{-1}$ in the temperature range from 300 to $580^{\circ} \mathrm{C}$. The total conversion of hexane above $400^{\circ} \mathrm{C}$ was practically $100 \%$. Yields of various hydrocarbons over $\mathrm{H}-\mathrm{ZSM}-5$ are shown in Fig. 1. At $300^{\circ} \mathrm{C}$, the preponderant products were $\mathrm{C}_{4}+\mathrm{C}_{4}{ }^{\prime}$ (hydrocarbons with four carbon atoms). At $450^{\circ} \mathrm{C}$, propane was most preponderant, and propane, butanes, and butenes accounted for $80 \%$ of the entire products. At higher temperatures, yields of these compounds decreased and those of methane and ethane, most unfavorable pro-

Table 1 Gonversion of Lower Alkanes over ZSM-5 Zeolites

\begin{tabular}{|c|c|c|c|c|c|c|c|}
\hline \multirow{2}{*}{ 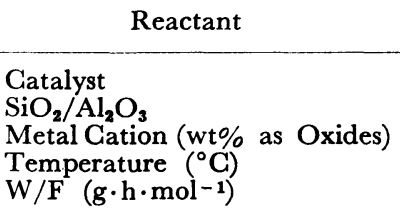 } & \multicolumn{3}{|c|}{$\mathrm{C}_{3} \mathrm{H}_{8}$} & \multicolumn{2}{|c|}{$n-\mathrm{C}_{5} \mathrm{H}_{12}$} & \multicolumn{2}{|c|}{$n-\mathrm{C}_{6} \mathrm{H}_{14}$} \\
\hline & $\begin{array}{c}\text { H-ZSM-5 } \\
47 \\
0 \\
550 \\
40.8\end{array}$ & $\begin{array}{c}\text { Ga-ZSM-5 } \\
47 \\
1.6 \\
550 \\
10.8\end{array}$ & $\begin{array}{c}\text { Zn-ZSM-5 } \\
47 \\
2.7 \\
550 \\
10.8\end{array}$ & $\begin{array}{c}\text { H-ZSM-5 } \\
52 \\
0 \\
550 \\
14.6\end{array}$ & $\begin{array}{c}\text { Ga-ZSM-5 } \\
52 \\
2.2 \\
550 \\
14.6\end{array}$ & $\begin{array}{l}\text { H-ZSM-5 } \\
42 \\
0 \\
580 \\
35.2\end{array}$ & $\begin{array}{c}\text { Ga-ZSM-5 } \\
42 \\
1.8 \\
580 \\
35.2\end{array}$ \\
\hline $\begin{array}{l}\text { Conversion }(\%) \\
\text { Yield of Aromatics }(\%)\end{array}$ & $\begin{array}{l}56.3 \\
16.9\end{array}$ & $\begin{array}{l}85.5 \\
61.7\end{array}$ & $\begin{array}{l}72.5 \\
36.1\end{array}$ & $\begin{array}{l}99.2 \\
24.0\end{array}$ & $\begin{array}{l}98.1 \\
51.2\end{array}$ & $\begin{array}{l}100 \\
16.1\end{array}$ & $\begin{array}{l}100 \\
65.0\end{array}$ \\
\hline $\begin{array}{l}\text { Product Distribution (\%) } \\
\qquad \mathrm{CH}_{4}+\mathrm{C}_{2} \mathrm{H}_{6} \\
\mathrm{C}_{2} \mathrm{H}_{4}+\mathrm{C}_{3} \mathrm{H}_{6} \\
\mathrm{C}_{3} \mathrm{H}_{8} \\
\mathrm{C}_{4} \mathrm{H}_{8}+\mathrm{C}_{4} \mathrm{H}_{10} \\
\mathrm{C}_{5}+ \\
\text { Aromatics }\end{array}$ & $\begin{array}{r}43.0 \\
20.9 \\
- \\
5.0 \\
1.1 \\
30.0\end{array}$ & $\begin{array}{r}22.7 \\
4.2 \\
- \\
0.7 \\
0.2 \\
72.2\end{array}$ & $\begin{array}{r}42.3 \\
6.5 \\
- \\
1.2 \\
0.1 \\
49.9\end{array}$ & $\begin{array}{r}32.0 \\
9.4 \\
29.1 \\
4.6 \\
0.7 \\
24.2\end{array}$ & $\begin{array}{c}17.7 \\
11.7 \\
14.2 \\
4.2 \\
0 \\
42.2\end{array}$ & $\begin{array}{r}55.7 \\
9.6 \\
14.7 \\
3.6 \\
0.3 \\
16.1\end{array}$ & $\begin{array}{l}33.5 \\
0.7 \\
0.8 \\
0 \\
0 \\
65.0\end{array}$ \\
\hline $\begin{array}{l}\text { Aromatics Distribution (\%) } \\
\text { Benzene } \\
\text { Toluene } \\
\text { Xylenes + Ethylbenzene } \\
\mathrm{G}_{\mathbf{0}^{+}}\end{array}$ & $\begin{array}{r}25.4 \\
46.2 \\
26.0 \\
2.4\end{array}$ & $\begin{array}{r}40.2 \\
40.7 \\
12.6 \\
6.5\end{array}$ & $\begin{array}{r}42.1 \\
36.9 \\
14.1 \\
6.9\end{array}$ & $\begin{array}{r}39.8 \\
49.4 \\
9.2 \\
1.6\end{array}$ & $\begin{array}{r}30.0 \\
45.1 \\
24.2 \\
0.7\end{array}$ & $\begin{array}{r}34.0 \\
47.5 \\
15.8 \\
2.7\end{array}$ & $\begin{array}{r}47.2 \\
38.8 \\
10.5 \\
3.5\end{array}$ \\
\hline
\end{tabular}




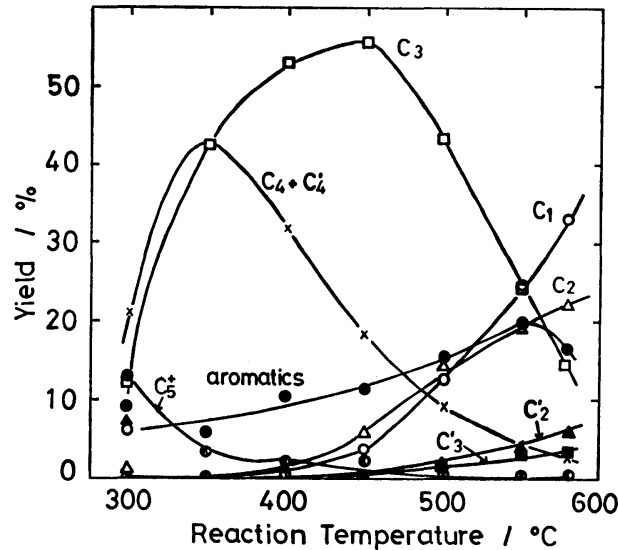

$\mathrm{W} / \mathrm{F}=35.2 \mathrm{~g} \cdot \mathrm{h} \cdot \mathrm{mol}^{-1}$, Hexane $=101 \mathrm{kPa}$

Fig. 1 Temperature Dependence of Product Distribution of Hexane Conversion over H-ZSM-5 $\left(\mathrm{SiO}_{2} / \mathrm{Al}_{2}-\right.$ $\mathrm{O}_{3}=42$ )

ducts, dominated. Yields of lower olefins, ethylene and propylene, were always small, reflecting higher reactivities of these substances. Yields of aromatics gradually increased with increasing reaction temperature and they reached $20 \%$ at $550^{\circ} \mathrm{C}$.

The temperature dependence of product distribution in hexane conversion over $\mathrm{Ga}-\mathrm{ZSM}-5\left(\mathrm{Ga}_{2} \mathrm{O}_{3}\right.$ $1.8 \mathrm{wt} \%$ ) is shown in Fig. 2. In this case, the catalyst was pretreated in a stream of hydrogen at $580^{\circ} \mathrm{C}$. The general features of temperature dependence over Ga-ZSM-5 were similar to those over H-ZSM-5. The most important difference between the two catalytic systems was the higher yield of aromatics over Ga-ZSM-5. The yield of aromatics increased greatly with increasing reaction temperature and it reached $65 \%$ at $580^{\circ} \mathrm{C}$.

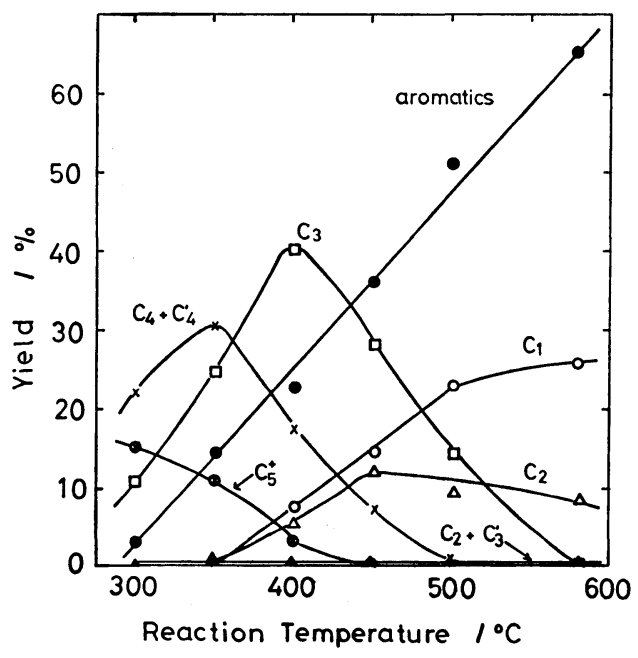

$\mathrm{W} / \mathrm{F}=35.2 \mathrm{~g} \cdot \mathrm{h} \cdot \mathrm{mol}^{-1}$, Hexane $=101 \mathrm{kPa}$

Fig. 2 Temperature Dependence of Product Distribution of Hexane Conversion over Ga-ZSM-5 $\left(\mathrm{SiO}_{2} / \mathrm{Al}_{2}-\right.$ $\mathrm{O}_{3}=42$

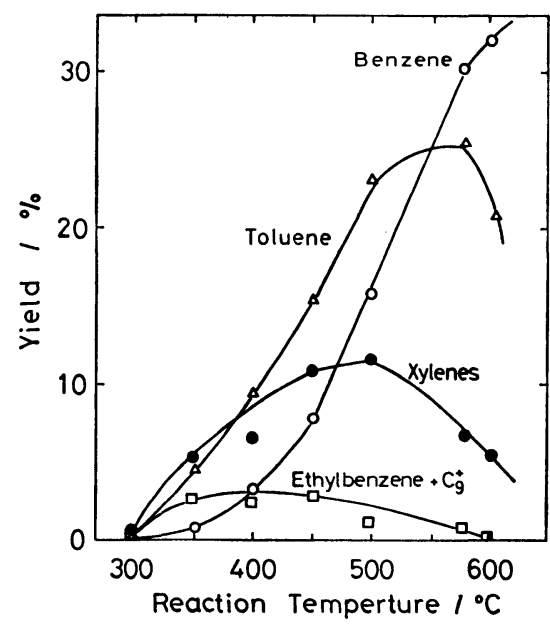

$\mathrm{W} / \mathrm{F}=35.2 \mathrm{~g} \cdot \mathrm{h} \cdot \mathrm{mol}^{-1}, \mathrm{Hexane}=101 \mathrm{kPa}$

Fig. 3 Temperature Dependence of the Yield of Aromatic Hydrocarbons in Hexane Conversion over Ga-ZSM-5 $\left(\mathrm{SiO}_{2} / \mathrm{Al}_{2} \mathrm{O}_{3}=42\right)$

The yield of lower paraffins, especially, of propane, decreased by Ga-loading.

The change in the yields of benzene, toluene, and xylenes over Ga-ZSM-5 with reaction temperature is shown in Fig. 3. At lower temperatures, toluene and xylenes were preponderant among the aromatics produced. The yield of benzene sharply increased with increasing reaction temperature, and above $550^{\circ} \mathrm{C}$, it became most predominant, while the yields of xylenes decreased above $400^{\circ} \mathrm{C}$. Demethylation of xylenes at higher temperatures will be discussed in the following sections.

Effect of contact time. As described above, there is hardly any doubt that gallium cations incorporated in the zeolite cavities play an important role in increasing the yields of aromatic hydrocarbons. To ascertain the reaction steps to which gallium cations contributed, the dependence of

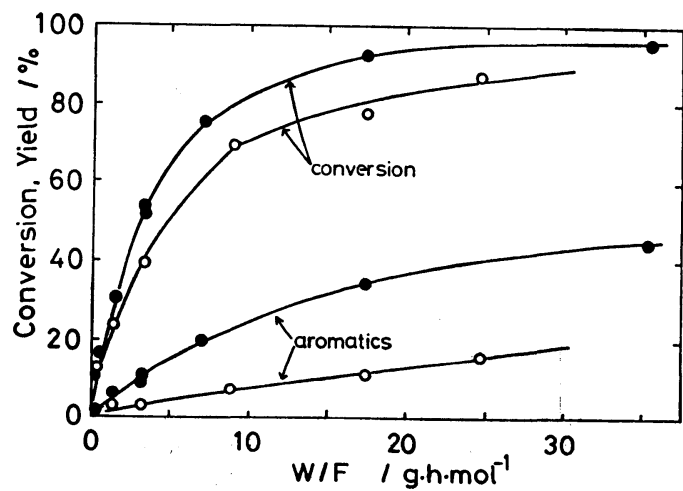

Temperature $=500^{\circ} \mathrm{C}$, Hexane $=101 \mathrm{kPa}$

Fig. 4 Effect of Contact Time on Total Conversion and Yield of Aromatics over H-ZSM-5 (O) and Ga-ZSM-5 (O) $\left(\mathrm{SiO}_{2} / \mathrm{Al}_{2} \mathrm{O}_{3}=210\right)$ 
yields of the various products on contact time in hexane conversion over H-ZSM-5 and Ga-ZSM-5 were compared. Two starting zeolites, differing in their $\mathrm{SiO}_{2} / \mathrm{Al}_{2} \mathrm{O}_{3}$ ratios (42 and 210), were used, both with and without $\mathrm{Ga}$-loading. The zeolites, with a higher $\mathrm{SiO}_{2} / \mathrm{Al}_{2} \mathrm{O}_{3}$ ratio $(=210)$, were chosen in order to observe the initial stages of hexane conversion. The dependence of total conversion and yield of aromatics on contact time over $\mathrm{H}-\mathrm{ZSM}-5$ and over $\mathrm{Ga}-\mathrm{ZSM}-5\left(\mathrm{SiO}_{2} / \mathrm{Al}_{2} \mathrm{O}_{3}=210\right)$ are shown in Fig. 4. The total conversion of hexane slightly increased by Ga-loading $\left(1.0 \mathrm{wt} \% \quad \mathrm{Ga}_{2} \mathrm{O}_{3}\right)$ while

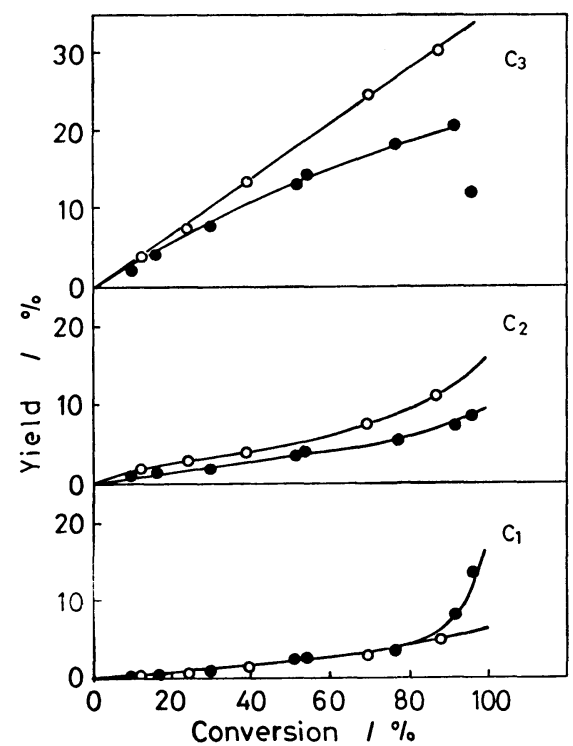

Fig. 5 The Yield of Lower Alkanes as a Function of Percentage Conversion of Hexane over H-ZSM-5 (O) and Ga-ZSM-5 (O) $\left(\mathrm{SiO}_{2} / \mathrm{Al}_{2} \mathrm{O}_{3}=210\right)$ at $500^{\circ} \mathrm{C}$

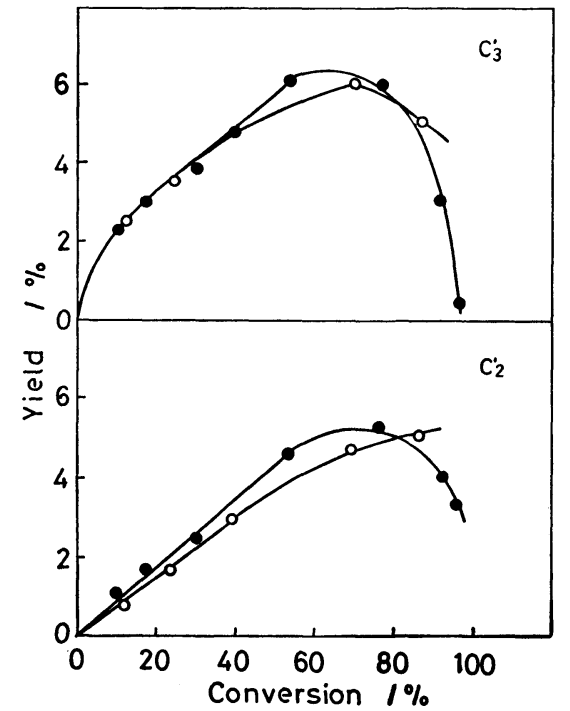

Fig. 6 The Yield of Ethylene and Propylene as a Function of Percentage Conversion of Hexane over H-ZSM-5 (O) and Ga-ZSM-5 (O) $\left(\mathrm{SiO}_{2} /\right.$ $\mathrm{Al}_{2} \mathrm{O}_{3}=210$ ) at $500^{\circ} \mathrm{C}$ the effect was much greater on the yields of aromatics. These observations indicate that the cracking activity or acidic properties of the zeolites will not be so greatly modified by Ga-loading, and gallium cations are much more effective for transforming the cracked products into aromatic hydrocarbons.

In Figs. 5 8, yields of various products over $\mathrm{H}-$ $\mathrm{ZSM}-5$ and $\mathrm{Ga}-\mathrm{ZSM}-5\left(\mathrm{SiO}_{2} / \mathrm{Al}_{2} \mathrm{O}_{3}=210\right)$ are plotted as a function of percentage conversion of hexane. The following features were readily observable:

(1) At early stage of hexane conversion $(<30$ $\%$, the yield of each product over $\mathrm{H}-\mathrm{ZSM}-5$ was very close to that over Ga-ZSM-5.

(2) Each of the yields of ethylene, propylene, $\left(\mathrm{C}_{4}+\mathrm{C}_{4}{ }^{\prime}\right)$ and $\left(\mathrm{C}_{5}+\mathrm{C}_{5}{ }^{\prime}\right)$ attains a maximum. The

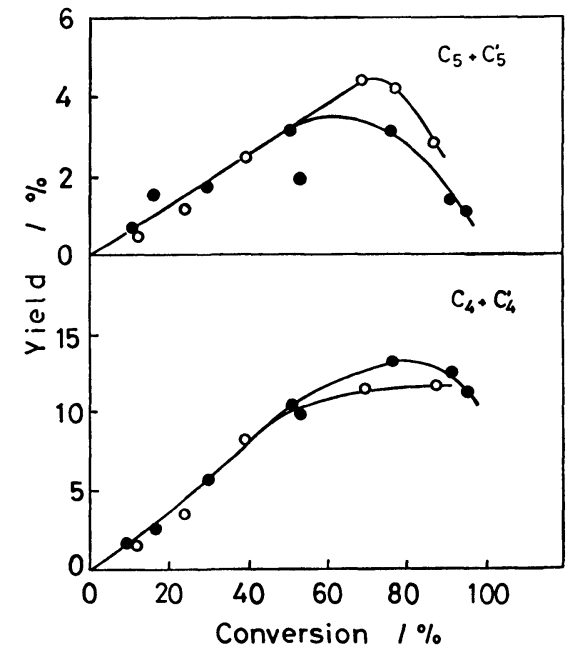

Fig. 7 The Yield of Hydrocarbons with Four and Five Carbon Atoms as a Function of Percentage Conversion of Hexane over H-ZSM-5 $(O)$ and Ga-ZSM-5 (@) $\left(\mathrm{SiO}_{2} / \mathrm{Al}_{2} \mathrm{O}_{3}=210\right)$ at $500^{\circ} \mathrm{C}$

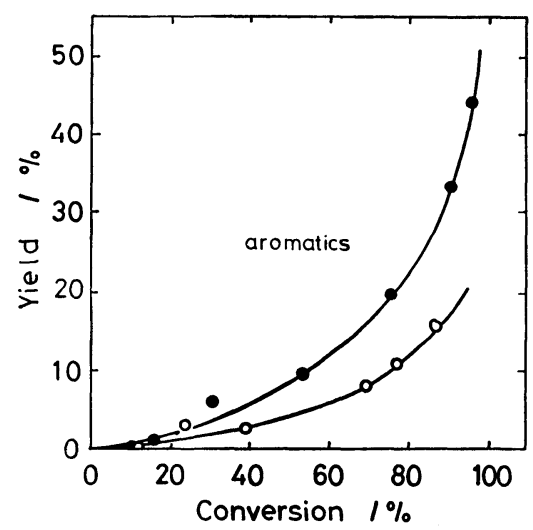

Fig. 8 The Yield of Aromatic Hydrocarbons as a Function of Percentage Conversion of Hexane over H-ZSM-5 $(O)$ and Ga-ZSM-5 $(\bullet)\left(\mathrm{SiO}_{2} /\right.$ $\mathrm{Al}_{2} \mathrm{O}_{3}=210$ ) at $500^{\circ} \mathrm{C}$ 
decline of the yield beyond the maximum was faster over Ga-ZSM-5 than over H-ZSM-5.

(3) The formation of aromatic hydrocarbons is significant only at higher conversion ranges both over H-ZSM-5 and Ga-ZSM-5.

(4) Yields of aromatic hydrocarbons are greater over Ga-ZSM-5.

(5) The yields of ethane and propane are greater over H-ZSM-5 than over Ga-ZSM-5.

Feature (1) is in agreement with the results shown in Fig. 4 that the rate of hexane conversion was not affected by Ga-loading. This implies that gallium cations have no part in the activation of hexane: thus, they exert no significant influence on the initial distribution of the cracking products.

Preponderant cracking products were propane and propylene. Methane and ethane were also found as primary products, indicating that cracking via non-classical, penta-coordinated carbonium ion intermediate ${ }^{21)}$ is also involved.

Feature (2) shows that lower olefins and aliphatic hydrocarbons with four or more carbon atoms are the intermediates for aromatization and that gallium ions promote the transformation of these intermediates into aromatics. Feature (3) is in conformity with feature (2), indicating that aromatics are not primary products from hexane. Feature (4) is also in conformity with feature (2), confirming that $\mathrm{Ga}$ ions are effective in converting intermediate products into aromatics.

Some of the features are more clearly seen in the

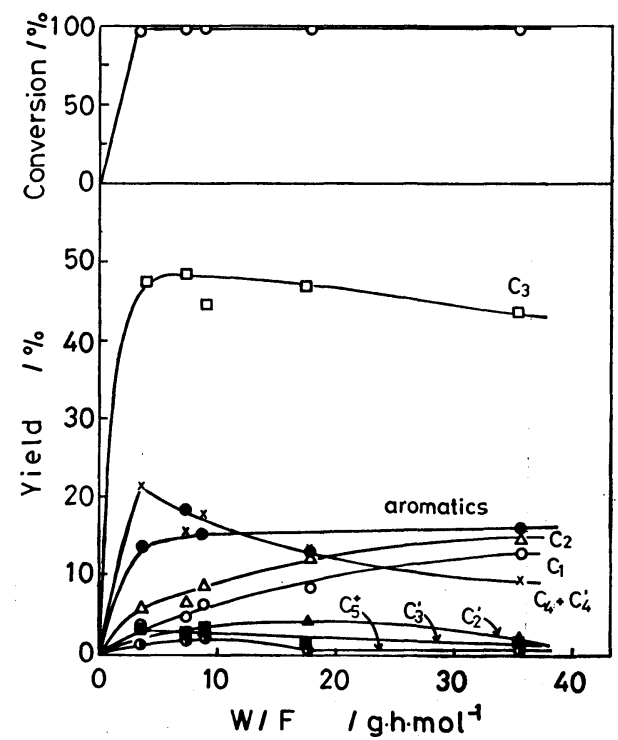

Temperature $=500^{\circ} \mathrm{C}$, Hexane $=101 \mathrm{kPa}$

Fig. 9 Effect of Contact Time on Total Conversion and Yields of Hydrocarbons in Hexane Conversion over H-ZSM-5 $\left(\mathrm{SiO}_{2} / \mathrm{Al}_{2} \mathrm{O}_{3}=42\right)$

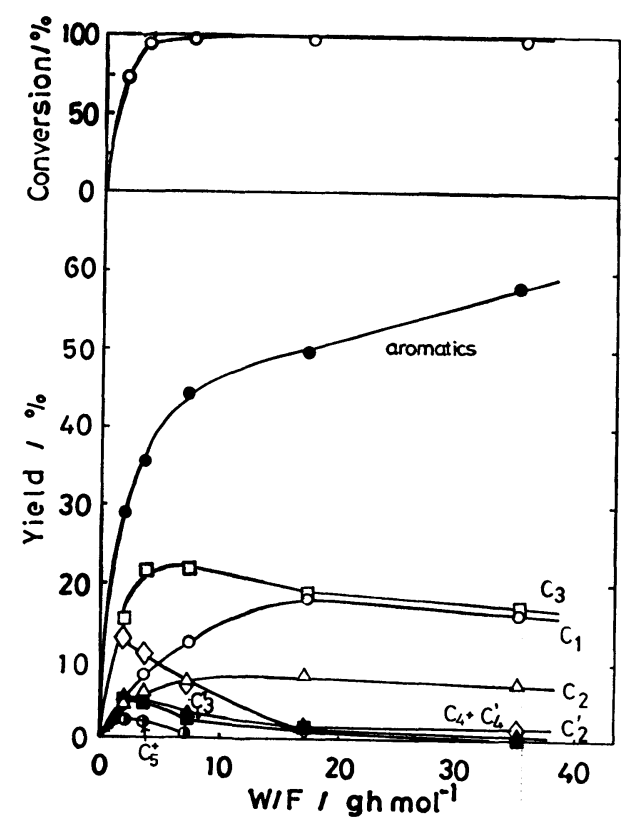

Temperature $=500^{\circ} \mathrm{C}$, Hexane $=101 \mathrm{kPa}$

Fig. 10 Effect of Contact Time on Total Conversion and Yields of Hydrocarbons in Hexane Conversion over Ga-ZSM-5 $\left(\mathrm{SiO}_{2} / \mathrm{Al}_{2} \mathrm{O}_{3}=42\right)$

conversion over more active catalysts. In Figs. 9 and 10, are shown the dependence of total conversion and yields of the various products on contact time in hexane conversion over $\mathrm{H}-\mathrm{ZSM}-5$ and over Ga-ZSM-5 $\left(\mathrm{SiO}_{2} / \mathrm{Al}_{2} \mathrm{O}_{3}=42\right)$, respectively. Both figures show that hexane is almost completely consumed at shorter contact time. The intermediacy of lower olefins and aliphatic hydrocarbons with four or more carbon atoms is clear, since each of the yields of these products goes through a maximum. Propane is less reactive; it starts to be transformed when other reactive substances are almost consumed. The obvious characteristics of the conversion over Ga-ZSM-5 compared with those of H-ZSM-5 are (1) the faster decay of lower olefins (2) higher yields of aromatics and (3) lower yield of propane. These three characteristics were also observed in the conversion over ZSM-5 with $\mathrm{SiO}_{2} /$ $\mathrm{Al}_{2} \mathrm{O}_{3}$ of 210 , but they are more clearly observed here. The third characteristic may need some comments. Propane is one of the most prevailing products from the cracking of intermediate hydrocarbons. Gallium-loading enhances the rate of aromatization of the intermediate hydrocarbons. This results in the relative depression of the rate of cracking of the intermediates. This in turn leads to a smaller yield of propane, one of products of cracking. All the features found in hexane conversion were found also in the conversion of pentane. ${ }^{14)}$ 
Dependence of the yields of the various aromatic products over $\mathrm{Ga}-\mathrm{ZSM}-\overline{5}$ on contact time is shown in Fig. 11. Each aromatic hydrocarbon behaved differently. Yields of toluene and benzene increased with increasing contact time. On the other hand, xylenes, as a whole, were the predominant aromatic products at lower contact time, but their yields rather decreased with increasing contact time, indicating that xylenes once formed undergo further reactions and transformed into other substances.

In order to understand the reactions of xylenes, the reaction of $m$-xylene was carried out at $500^{\circ} \mathrm{C}$

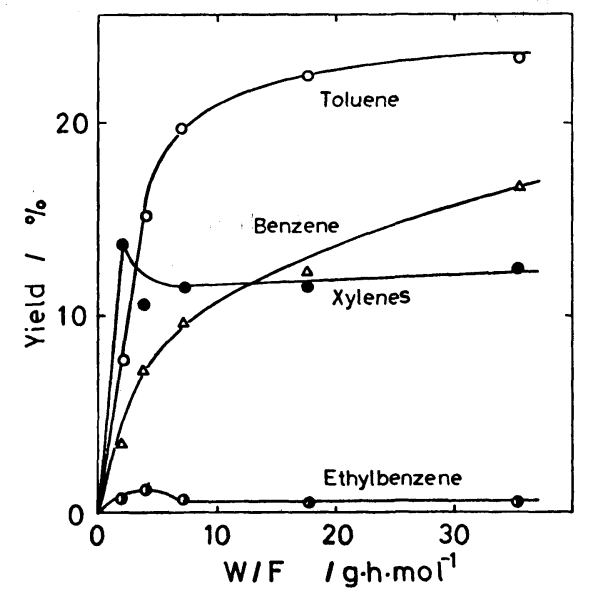

Temperature $=500^{\circ} \mathrm{C}$, Hexane $=101 \mathrm{kPa}$

Fig. 11 Change in Yields of Aromatic Hydrocarbons with Contact Time in Hexane Conversion over Ga-ZSM-5 $\left(\mathrm{SiO}_{2} / \mathrm{Al}_{2} \mathrm{O}_{3}=42\right)$

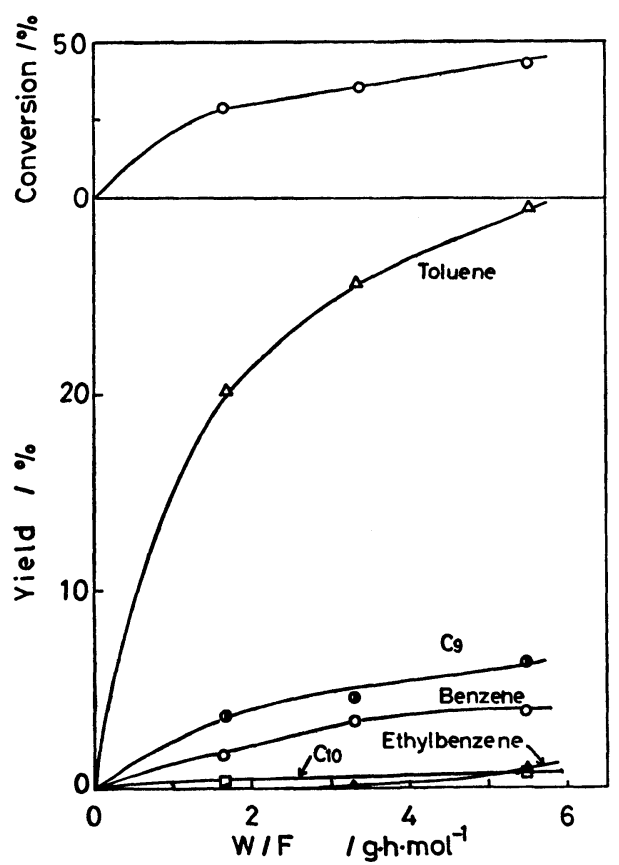

Temperature $=500^{\circ} \mathrm{C}$, Xylene $=10 \mathrm{kPa}$

Fig. 12 The Yield of Aromatic Hydrocarbons in the Reaction of $m$-Xylene over Ga-ZSM-5 over $\mathrm{Ga}-\mathrm{ZSM}-5\left(\mathrm{SiO}_{2} / \mathrm{Al}_{2} \mathrm{O}_{3}=42\right)$. As shown in Fig. 12, various aromatic compounds were formed besides $o$ - and $p$-xylene. Methane was the only product other than the aromatics. The predominant product was toluene, which far exceeded the amount of trimethylbenzenes, indicating that toluene is produced mainly by demethylation of xylenes, but not by disproportionation. These observations explain the decrease in the net rate of xylene formation at longer contact time in hexane conversion. This is further confirmed by the reaction of a mixture of hexane and $m$-xylene $(22 \mathrm{~mol} \%$ ) over $\mathrm{Ga}-$ ZSM-5 at $500^{\circ} \mathrm{C}$. Although benzene and toluene were produced as expected, the amount of xylenes in the products was smaller than that in the feed. Thus, the rate of formation of xylenes from hexane was slower than the rate of demethylation of xylenes.

Reaction of $m$-xylene over $\mathrm{H}-\mathrm{ZSM}-5$ was quite similar to that over Ga-ZSM-5. However, ethylene, propylene, and propane were found in the products besides methane, indicating the destruction of aromatic rings.

\subsection{Conversion of Propylene over ZSM-5}

The results of conversion of hexane suggest that metal cations are responsible for the transformation of lower olefins into aromatics. According to the idea, it is essential to examine the behavior of olefins towards metal cations under the reaction conditions. Thus, reactions of propylene over $\mathrm{H}$ ZSM-5 and Zn-ZSM-5 were studied.

The effect of reaction temperature on the product distribution in the conversion of propylene over $\mathrm{H}-\mathrm{ZSM}-5\left(\mathrm{SiO}_{2} / \mathrm{Al}_{2} \mathrm{O}_{3}=47\right)$ is shown in Fig.

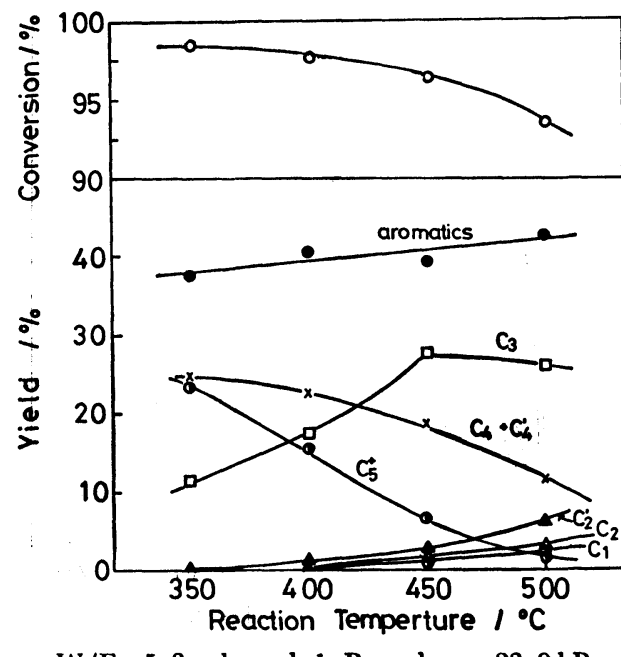

$\mathrm{W} / \mathrm{F}=5.3 \mathrm{~g} \cdot \mathrm{h} \cdot \mathrm{mol}^{-1}$, Propylene $=23.0 \mathrm{kPa}$

Fig. 13 Change in Product Distribution with Reaction Temperature in the Conversion of Propylene over H-ZSM-5 


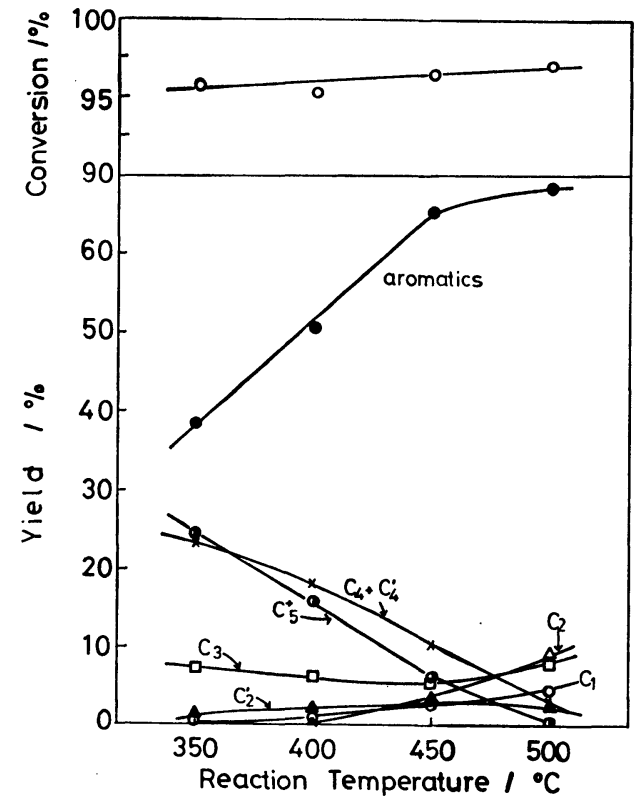

$\mathrm{W} / \mathrm{F}=5.3 \mathrm{~g} \cdot \mathrm{h} \cdot \mathrm{mol}^{-1}$, Propylene $=23.0 \mathrm{kPa}$

Fig. 14 Change in Product Distribution with Reaction Temperature in the Conversion of Propylene over Zn-ZSM-5

13. In the temperature range studied, the conversion was always over $95 \%$, and aliphatic hydrocarbons with four or more carbon atoms were the main products at and above $350^{\circ} \mathrm{C}$. At higher temperatures, yields of these products decreased, and those of lower hydrocarbons increased, instead. The yield of aromatic hydrocarbons was almost constant $(40 \%)$ in the temperature range from 350 to $600^{\circ} \mathrm{C}$. Yields of methane and ethane increased at higher temperatures, indicating that cracking of the oligomerized products had occurred.

In Fig. 14, the effect of reaction temperature on product distribution was also examined for propylene conversion over $\mathrm{Zn}-\mathrm{ZSM}-5\left(\mathrm{SiO}_{2} / \mathrm{Al}_{2} \mathrm{O}_{3}=\right.$ $47, \mathrm{ZnO} 2.7 \mathrm{wt} \%$ ). In contrast to the conversion over H-ZSM-5, the yield of aromatics was high especially at higher temperatures; the yields were as high as $68.2 \%$ at $500^{\circ} \mathrm{C}$. It is worthy of note that the yield of propane is much smaller over $\mathrm{Zn}$ ZSM-5 than that over H-ZSM-5.

Propane may be produced by hydride transfer between carbenium ion (I) and olefin molecule.

$$
\begin{aligned}
& \mathrm{H}_{3} \mathrm{C}-\mathrm{CH}-\mathrm{CH}_{3}+\mathrm{R}-\mathrm{CH}=\mathrm{CH}-\mathrm{CH}_{2}-\mathrm{CH}_{2} \mathrm{R}^{\prime} \longrightarrow \\
& \stackrel{+}{(\mathrm{I})} \\
& \mathrm{CH}_{3} \mathrm{CH}_{2} \mathrm{CH}_{3}+\left[\mathrm{R}-\mathrm{CH}=\underset{\text { (II) }}{\longrightarrow}=\mathrm{CH}-\mathrm{CH}_{2} \mathrm{R}^{\prime}\right]^{+}
\end{aligned}
$$

The carbenium ion with longer carbon chains (II) may react with a propylene molecule to produce a smaller carbenium ion and a diolefin molecule.

$$
\begin{gathered}
\mathrm{CH}_{3}-\mathrm{CH}=\mathrm{CH}_{2}+\left[\mathrm{R}-\mathrm{CH}=\mathrm{CH}=\mathrm{CH}-\mathrm{CH}_{2}-\mathrm{R}^{\prime}\right]^{+} \\
\mathrm{CH}_{3}-\mathrm{CH}-\mathrm{CH}_{3}+\mathrm{RCH}=\mathrm{CH}-\mathrm{CH}=\mathrm{CH}-\mathrm{R}^{\prime}
\end{gathered}
$$

Repetition of reactions (1) and (2) leads to the formation of smaller alkanes like propane and diolefins with longer carbon chains. Further dehydrogenation of the diolefins may give aromatic hydrocarbons with simultaneous formation of lower alkanes. Thus, if we represent the olefin by propylene and the aromatics by benzene, the overall reaction could be represented as follows, since longer olefins, or hexenes in this case, may be formed by dimerization of propylene:

$$
5 \mathrm{C}_{3} \mathrm{H}_{6} \longrightarrow \mathrm{C}_{6} \mathrm{H}_{6}+3 \mathrm{C}_{3} \mathrm{H}_{8}
$$

This shows that the formation of one aromatic hydrocarbon molecule inevitably leads to the simultaneous formation of three molecules of alkanes. Therefore, it is not possible to obtain a high yield of aromatics so long as dehydrogenation of the intermediate olefins proceeds by hydride transfer mechanism.

Higher yields of aromatics from propylene over Zn-ZSM-5, thus, raise the argument that another mechanism of olefin dehydrogenation might be operative in this case. We presume, here, direct elimination of hydrogen from the olefin. Actually, the formation of hydrogen was observed over $\mathrm{Zn}$--ZSM5 , while it was observed but negligibly over $\mathrm{H}$ ZSM-5. If direct dehydrogenation was operative, the overall reaction would be expressed as

$$
2 \mathrm{C}_{3} \mathrm{H}_{6} \longrightarrow \mathrm{C}_{6} \mathrm{H}_{6}+3 \mathrm{H}_{2}
$$

Then, the maximum theoretical yield of aromatics from olefins is $100 \%$. Practically, however, since Zn-ZSM-5 has acidic centers, and the hydridetransfer mechanism is always operative together with direct dehydration mechanism, the actual yield of aromatics must be less than $100 \%$.

Aromatic hydrocarbons formed from propylene were not only benzene and $\mathrm{C}_{\mathbf{9}}$-aromatics, but they contained appreciable amount of toluene and xylenes. Thus, the distribution (in molar percentage) of aromatics produced at $500^{\circ} \mathrm{C}$ over $\mathrm{H}-\mathrm{ZSM}-5$ and over $\mathrm{Zn}-\mathrm{ZSM}-5$ were as follows: over $\mathrm{H}$ ZSM-5, benzene $20.5 \%$, toluene $44.6 \%$, xylenes $28.7 \%$, ethylbenzene $1.7 \%, \mathrm{C}_{9}+4.5 \%$; over $\mathrm{Zn}-$ ZSM-5, benzene $32.0 \%$, toluene $40.8 \%$, xylenes $21.9 \%$, ethylbenzene $0.9 \%, \mathrm{C}_{9}+4.4 \%$.

The variety of aromatics found is a reflection of the distribution of olefins in the system. As seen in Figs. 13 and 14, ethylene, butenes, and pentenes exist in the system besides the original propylene. These olefins may be formed by cracking of the oligomerization products of propylene, and these 
olefins may also oligomerize to give heavier products. Repetition of oligomerization of lower olefins and cracking of the oligomerization products lead to the formation of a variety of olefins, which in turn yield a variety of oligomerization products (or carbenium ions with longer carbon chains), which are the intermediates for aromatics. Differences in oligomers in turn effect differences in aromatics. Moreover, the distribution of aromatics is modified by dealkylation of the primary aromatic hydrocarbons, as described in the preceding section.

\subsection{Conversion of Propylene over Zn-Boro- silicate}

As described above, the bifunctional nature of the catalysts is important for aromatization of olefins. The acidic sites are responsible for oligomerization of olefins and the metal cations are responsible for dehydrogenation of olefins or oligomerized products. Acidic sites are responsible for cracking of oligomers and for hydrogen transfer reactions. Therefore, when the acidic nature of the catalyst is modified, the overall catalytic processes in the zeolite cavities would be greatly modified and the rate and selectivity of the reactions would be greatly altered.

Acid strengths of borosilicates are known to be very weak in comparison to those of aluminosilicates ${ }^{15) ~ 17)}$, and borosilicates still have ion exchange capacity. Here, a borosilicate $\left(\mathrm{SiO}_{2} / \mathrm{B}_{2} \mathrm{O}_{3}=25\right)$ with the ZSM-5 structure was synthesized, and the conversion of propylene over $\mathrm{H}$-borosilicate and over its ion-exchanged form was studied.

Fig. 15 shows the product distribution observed in the reactions of propylene over $\mathrm{H}$-borosilicate.

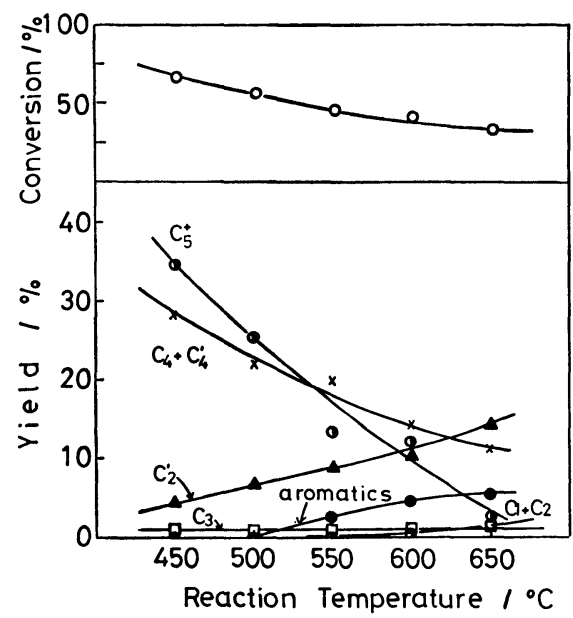

$\mathrm{W} / \mathrm{F}=5.3 \mathrm{~g} \cdot \mathrm{h} \cdot \mathrm{mol}^{-1}$, Propylene $=23.0 \mathrm{kPa}$

Fig. 15 Change in Product Distribution with Reaction Temperature in the Conversion of Propylene over H-Borosilicate
There are distinct differences in the distribution from the conversion over $\mathrm{H}-\mathrm{ZSM}-5$ (Fig. 13). First of all, the total conversion was smaller over H-borosilicate than over H-ZSM-5. The conversion over $\mathrm{H}$-borosilicate was smaller at higher temperatures; $69.5 \%$ at $450^{\circ} \mathrm{C}$ and $36.8 \%$ at $650^{\circ} \mathrm{C}$, respectively. This may be the reflection of the equilibrium of dimerization of propylene and depolymerization of the dimers. The main products were olefins, and the formation of paraffins like propane was very small (Fig. 15). This indicates that hydride-transfer between carbenium ions and olefins proceeds negligibly in the cavities of the borosilicate. Another important feature of the borosilicate is small yields of aromatics, suggesting again that hydride-transfer reactions occur but negligibly.

Fig. 16 shows the distribution of products resulted from the reaction of propylene over $\mathrm{Zn}$-borosilicate $(\mathrm{Zn}, 2.1 \mathrm{wt} \%$ as $\mathrm{ZnO})$. In contrast to its reaction over H-borosilicate, aromatic hydrocarbons were formed, though the yields were smaller than those formed over Zn-ZSM-5. A maximum in the yield of aromatics appeared at $600^{\circ} \mathrm{C}$. The decrease in the yield at higher temperatures may be caused by deactivation of the catalyst. The data given in Fig. 16 are those taken $1 \mathrm{~h}$ after the start of reaction. The yield of propane was very small $(5.5 \%)$ even at $600^{\circ} \mathrm{C}$, indicating that aromatics were produced by direct dehydrogenation of olefins or oligomers, and not by intermolecular hydride transfer. This is a clear demonstration of the dehydrogenation activity of the zinc species.

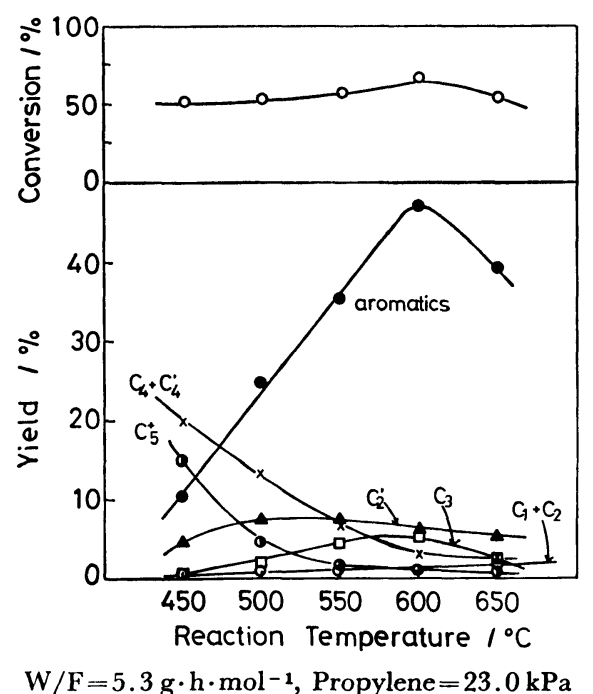

Fig. 16 Change in Product Distribution with Reaction Temperature in the Conversion of Propylene over Zn-Borosilicate 


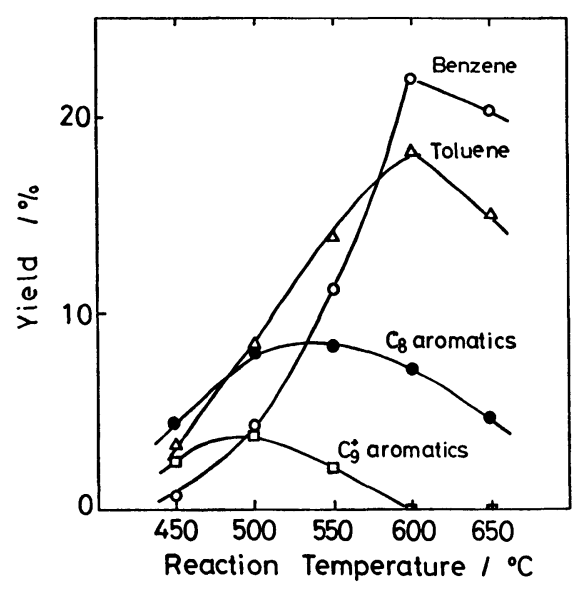

$\mathrm{W} / \mathrm{F}=5.3 \mathrm{~g} \cdot \mathrm{h} \cdot \mathrm{mol}^{-1}$, Propylene $=23.0 \mathrm{kPa}$

Fig. 17 Effect of Reaction Temperature on Yields of Aromatic Hydrocarbons in the Conversion of Propylene over Zn-Borosilicate

In Fig. 17, are shown the yields of aromatic hydrocarbons resulted from conversion of propylene. At $450^{\circ} \mathrm{C}$, the aromatics consisted of $65 \%$ xylenes and heavier aromatics. The fraction of these products decreased at higher temperatures but the yield of benzene, on the other hand, increased; at $600^{\circ} \mathrm{C}$, benzene accounted for a half of the aromatic products. The lower yield of methane indicated that benzene was not formed by dealkylation of toluene or xylenes, but it was a primary aromatic product.

This was further confirmed by looking into the initial aromatic products at $580^{\circ} \mathrm{C}$ under the conditions of shorter contact times and lower propylene pressures. Under these conditions, conversion of propylene was low, and catalyst deactivation was appreciable as shown in Fig. 18(a), where the changes in propylene conversion and yields of aromatics with time on stream are shown. Selectivities of benzene, toluene, and xylene vs. propylene conversion are shown in Fig. 18(b). The fraction of benzene was high at the beginning but it decreased with increasing level of total conversion while the fractions of toluene and xylenes increased.

The selectivity to benzene could be extrapolated to $100 \%$, while that to toluene and to xylene to $0 \%$ at zero conversion of propylene. This shows that benzene could be the only aromatic product if propylene was the only olefin in the system. The formation of toluene and xylenes in later stages may be brought about by the formation of other olefins by succesive reactions: oligomerization of propylene, isomerization of the oligomers, and cracking of the isomerized products. It should be noted that an appreciable amount of butadiene was produced from 1-butene under similar reaction conditions, indicating the possibility of direct dehydrogenation of olefins by zinc species.

Kokes and coworkers ${ }^{22}$ ) made detailed studies on the adsorption of propylene on zinc oxide and found the formation of allylic species on the surface. Seiyama and coworkers ${ }^{23}$ ) found the formation of benzene as the main product in the oxidation of propylene over zinc oxide. These findings suggest that zinc species in ZSM-5 are also effective in forming allylic species from propylene or from its oligomers by direct abstraction of hydrogen atom (or hydride). Benzene could be formed from two allyl species. Acidic zeolites like Zn-ZSM-5, over which oligomerization and cracking are more prevailing, various types of olefins are formed in the zeolite pores, and various types of aromatics could be formed from a variety of allylic species. If the allylic species have four or more carbon atoms, further abstraction of hydrogen atoms may occur to produce diolefins. As mentioned elsewhere, the reaction of 1 -butene over $\mathrm{Zn}$-borosilicate yielded, with high selectivity, butadiene. If the carbon
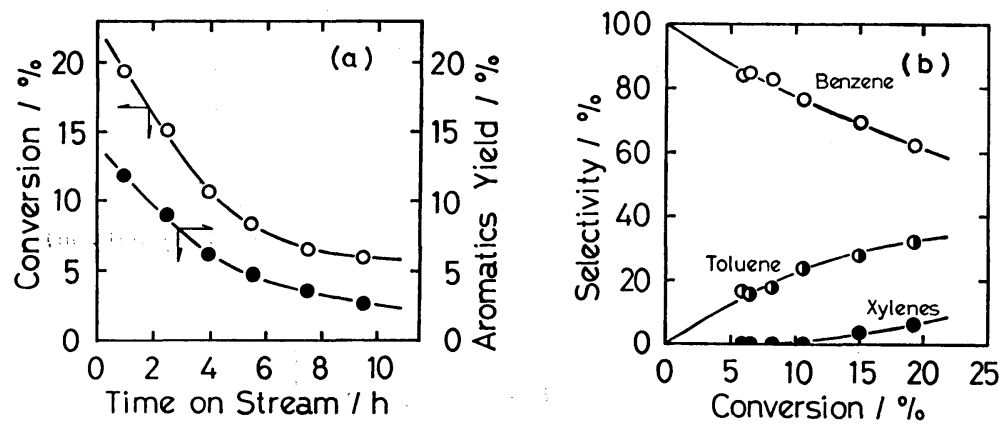

Temperature $=873 \mathrm{~K}$, Propylene $=5 \mathrm{kPa}, \mathrm{W} / \mathrm{F}=1.1 \mathrm{~g} \cdot \mathrm{h} \cdot \mathrm{mol}^{-1}$

Fig. 18 (a) Change in Total Conversion and Yiẹld of Aromatics with Time on Stream, and (b) Change in Selectivity to Benzene, Toluene, and Xylenes among Aromatic Hydrocarbons with Total Conversion in the Reaction of Propylene over $\mathrm{Zn}$-Borosilicate 
number of diolefins are six or more, further abstraction of hydrogen could proceed to give finally aromatic compounds. Thus, there might be two routes for the formation of aromatic hydrocarbons: direct coupling of two allylic species, and successive dehydrogenation of higher olefins.

\subsection{Conversion of Propane over Borosili- cates}

Reactions of propane over borosilicates were studied under the following conditions: temperature, $550^{\circ} \mathrm{C}$; propane pressure $101.3 \mathrm{kPa}$; and $\mathrm{W} / \mathrm{F}$ $=10.8 \mathrm{~g} \cdot \mathrm{h} \cdot \mathrm{mol}^{-1}$. Under these conditions, total conversion of propane over $\mathrm{H}$ - and $\mathrm{Zn}$-borosilicate were $1.8 \%$ and $2.6 \%$, respectively. Low conversions of propane over these borosilicates indicates that zinc cations are not responsible for activation of propane. This is not in conformity with the conclusion of Mole et al., ${ }^{12)}$ that zinc cations abstract hydrogen atoms from propane molecules. The results in a previous section clearly showed that zinc species promoted aromatization by abstracting hydrogen molecules from olefins.

The difference between catalytic activities of ZSM-5 and borosilicates for propane conversion is due, undoubtedly, to the difference in the acidic strengths of the zeolites. Thus, the acid strength of $\mathrm{OH}$ groups in borosilicates are too weak to activate propane molecules.

\subsection{General Reaction Scheme}

Based on the results and discussion given in preceding sections, the general pathway of the conversion of alkanes over ZSM- 5 zeolites can be summarized in a scheme shown in Fig. 19.

\section{(i) H-ZSM-5}

(a) Lower paraffins undergo cracking over Brönsted sites of the zeolites to give lower olefins and smaller paraffins. Among smaller paraffins, methane and ethane are the end products since they are not reactive under the reaction conditions. The main cracking products, propane and isobutane, undergo further cracking.

(b) Lower olefins formed by cracking of alkanes dimerize to yield higher olefins which undergo cracking to regenerate give lower olefins. Isomerization of olefins proceeds simultaneously with dimerization and cracking. The combination of these reactions leads to the formation of a variety of olefins irrespective of the kinds of starting hydrocarbons. This is reflected to the fact that distribution of aromatics is independent of the kinds of starting hydrocarbons.

(c) Olefins also undergo hydride abstraction. Repeated hydride abstraction and deprotonation of higher olefins yield aromatics. At the same time, paraffins are reproduced by hydride transfer to carbenium ions. The formation of one aromatic molecule leads inevitably to the formation of three paraffin molecules. This formation pattern restricts the yield of aromatics.

(d) Dealkylation of alkyl aromatics also proceeds to give methane and less substituted aromatics.

\section{(ii) Ga-ZSM-5 and Zn-ZSM-5}

(a) All elementary reactions found over $\mathrm{H}$ ZSM-5 proceed also over both Ga-ZSM-5 and Zn-ZSM- 5 by action of Brönsted acid sites.

(b) Introduction of $\mathrm{Ga}$ - or $\mathrm{Zn}$ - ions gives rise to dehydrogenation activity. Butadiene is formed

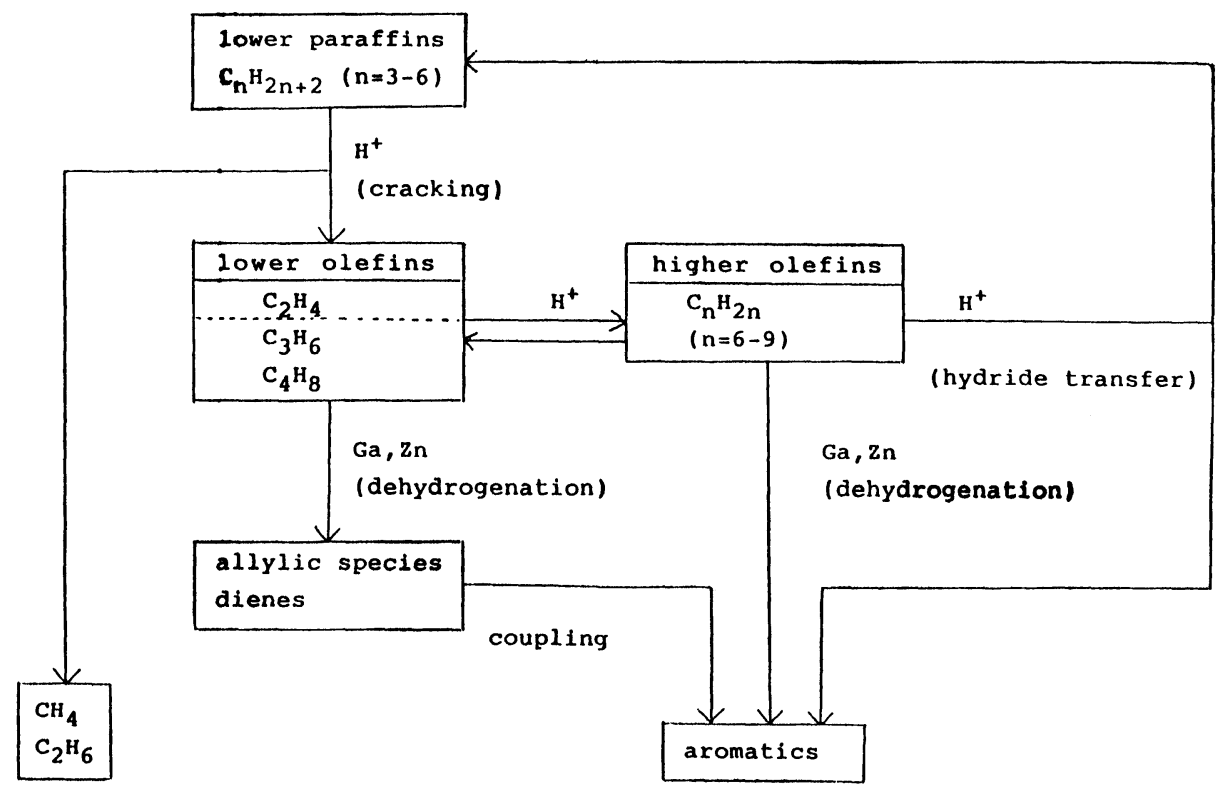

Fig. 19 The Reaction Scheme of Alkane Conversion 
from butenes; allylic species may be formed from propylene. The coupling of the allylic species or butadiene may yield aromatic hydrocarbons.

(c) In the case of higher olefins, successive dehydrogenation also gives aromatic hydrocarbons.

(d) Since the formation of aromatics through dehydrogenation of olefins by metal cations does not require coproduction of paraffins, higher yields of aromatics can be attained over Ga-ZSM- 5 and over Zn-ZSM-5.

\section{References}

1) Csicsery, S. M., J. Catal., 17, 205 (1970).

2) Csicsery, S. M., J. Catal., 17, 217 (1970).

3) Csicsery, S. M., J. Catal., 17, 315 (1970).

4) Csicsery, S. M., J. Catal., 17, 322 (1970).

5) Csicsery, S. M., J. Catal., 18, 30 (1970).

6) Bragin, O. V., Vasina, T. V., Isakov, Ya. I., Nefedov, B. K., Preobrazhenskii, A. V., Palishkina, N. V., Minachev, N. M., Izv. Akad. Nauk SSSR, Ser. Khim., 954 (1982).

7) Bragin, O. V., Vasina, T. V., Isakov, Ya. I., Palishkina, N. V., Preobrazhenskii, A. V., Izv. Akad. Nauk SSSR, Ser. Khim., 2002 (1983).

8) Bragin, O. V., Vasina, T. V., Preobrazhenskii, A. V.,
Izv. Akad. Nauk, Ser. Khim., 56 (1984).

9) Inui, T., Okazumi, F., J. Catal., 90, 366 (1984).

10) US $4,120,910$.

11) US $4,180,689$.

12) Mole, T., Anderson, J. R., Creer, G., Applied Catal., 17, 141 (1985).

13) Kitagawa, H., Sendoda, Y., Ono, Y., J. Catal., 101, 12 (1986).

14) Sirokman, G., Sendoda, Y., Ono, Y., Zeolites, 6, 299 (1986).

15) Acholle, K. F. G. J., Kentgens, A. P. M., Veeman, W. S., Frenken, P., Valdin, G. P. M. V., J. Phys. Chem. 88, 5 (1984).

16) Chu, C. T-W., Chang, C. D., J. Phys. Chem., 89, 1569 (1985).

17) Chu, G. T-W., Kuehl, G. H., Lago, R. M., Chang, C. D., J. Catal., 93, 451 (1985).

18) Brit. $1,402,981$.

19) Jacobs, P. A., J. Phys. Chem., 86, 300 (1982).

20) U.S. $3,902,886$.

21) Haag, W. O., Dessau, R. M., Proc. 8th. Int. Congr. Catalysis, West Berlin, 1984, II-305.

22) Kokes, P. J., Dent, A. L., Advances in Catalysis, 22, 1 (1972).

23) Seiyama, T., Yamazoe, N., Egashira, M., Proc. 5th Intern. Congr. Catal. (J. W. Hightower ed.), Vol. 1, p. 997 North Holland, 1973, Amsterdam. 


\title{
ZSM-5 ゼオライトを触媒とする低級アルカンの芳香族峞化水素への枟化反応
}

\author{
小野 嘉夫, 北川 弘佳, 仙洞田洋子 \\ 東京工業大学工学部化学工学科, 152 東京都目黒区大岡山 2-12-1
}

ZSM-5 に上る低級アルカンの反応において，芳香族炭化水 素の収率は, ZSM-5 に Ga, Zn の金属カチオンを導入するこ とにより著しく增大した。例えば，プロパンの反応において， 全炭化水素生成物中に排子芳香族 炭化水素の 割合は, HZSM-5, Zn-ZSM-5, Ga-ZSM-5 で，それぞれ，30.0\%，49.9 $\%, 72.2 \%$ (炭素数基準) であった。

金属イオンの役割を明らかにするため, $n$-ヘキサンの反応を H-ZSM-5 と Ga-ZSM-5 を触媒として詳細に調べた。活性は 两者であまり大きな差がないのに対し, 芳香族炭化水素への選 択性は $\mathrm{Ga}$ の導入により著しく向上した。接触時間の短かい条 件では, $n$-ヘキサンのクラッキングが主に進行し, 両者の生成 物分布にはほとんど差がなかった。芳香族炭化水素の生成は, 接触時間の長いところで起こり, Ga-ZSM-5 の方がその収率 は高い。これらのことより, $\mathrm{Ga}$ カチオンは, アルカンの活性 化には関与せず，クラッキングにより生成したアルケンの芳香 族化に触媒作用を示すことを結論した。

プロピレンの転化反応を H-ZSM-5 と Zn-ZSM-5 で行っ た。芳香族炭化水素の収率はZn-ZSM-5 の方がはるか涪 い。また, プロパンの生成も Zn-ZSM-5 では抑えられた。こ の事実は，水素移行反応が抑制されていることを示しており，
芳香族炭化水素の生成に対して, カルベニウムイオンのオレフ ィンからの水素引き抜き反応を含まない生成機構が存在するこ とを明らかにした。結局, Zn カチオンはオレフィンからの直 接的脱水素反応を行う能力があるすのと結論した。

ゼオライトの酸触媒としての能力を抑え， Zn カチオンの役 割をはっきりさせるため, H-ボロシリケートおよび $\mathrm{Zn-ボ口}$ シリケートによるプロパン拈よびプロピレンの反応を行った。 これらの触媒はプロパンの反応に対してほとんど活性を示さな い。しかし，プロピレンの反応に対し，Zn-ボロシリケートは 高い芳香族選択性を与える。この事実も，Zn カチオンがアル カンの活性化には有効ではないが，オレフィンの芳香族化には 高活性であることを示している。 $600^{\circ} \mathrm{C}$ ，低接触時間の条件で は，芳香族生成物中に占めるベンゼンの割合が極めて高い。プ ロピレン 2 分子からの直接的ベンゼン生成過程が存在すること を示している。また，1-ブテンからは初期にはブタジェンを与 え, 芳香族中にはキシンンの生成率が高い。Zn 種が脱水素活 性をもつことを支持する結果である。Zn カチオンの存在によ り，オレフィンからアリル種が形成され，これが芳香族化の中 間体になるものと推論した。

\section{Keywords}

Aromatization, Gallium ZSM-5 zeolite, Hexane conversion, Zinc ZSM-5 zeolite, ZSM-5 zeolite 